Красинский Владислав Вячеславович

доктор юридических наук, член Общественного

консультативного научно-методического Совета

при ЦИК России

109012, г. Москва, Б. Черкасский пер. д. 4 стр. 2

\title{
О ПРАВОВЫХ ПОЗИЦИЯХ ЕВРОПЕЙСКОГО СУДА ПО ПРАВАМ ЧЕЛОВЕКА И КОНСТИТУЦИОННОГО СУДА РОССИЙСКОЙ ФЕДЕРАЦИИ ПО ВОПРОСАМ ОГРАНИЧЕНИЯ ИЗБИРАТЕЛЬНЫХ ПРАВ В СВЯЗИ С НАЛИЧИЕМ СУДИМОСТИ
}

Аннотация: в статье исследована прецедентная практика Европейского Суда по правам человека по вопросам защиты избирательных прав осужденных, проанализирован подход Конституционного Суда Российской Федерации в отношении критериев избираемости и права голоса заключенных.

Ключевые слова: Конституционный Суд Российской Федерации; Европейский суд по правам человека; ограничение избирательных прав; лишение избирательных прав; защита избирательных прав осужденных; антикриминальная политика.

Annote: The article investigated the case-law of the European Court of Human Rights to protect the electoral rights of convicted; the legal position of the Constitutional Court of the Russian Federation concerning an active and passive electoral rights of prisoners is analysed.

Key words: Constitutional Court of the Russian Federation; European Court of Human Rights; restriction of electoral rights; disfranchisement; protection of electoral rights of convicts; anti-criminal policy.

Красинский В.В. О правовых позициях Европейского Суда по правам человека и Конституционного Суда Российской Федерации по вопросам ограничения избирательных прав в связи с наличием судимости // Современное право. 2014. № 2. С. 34-41

Согласно части 3 статьи 32 Конституции Российской Федерации не обладают активным и пассивным избирательным правом граждане, признанные судом недееспособными или содержащиеся в местах лишения свободы по приговору суда ${ }^{1}$.

В соответствии с пунктом 3.2 статьи 4 Федерального закона от 12 июня 2002 г. № 67-Ф3:

«Не имеют права быть избранными граждане Российской Федерации:

а) осужденные когда-либо к лишению свободы за совершение тяжких и (или) особо тяжких преступлений, за исключением случаев, когда в соответствии с новым уголовным законом эти деяния не признаются тяжкими или особо тяжкими преступлениями;

1 В настоящее время в Российской Федерации лишены избирательных прав 734300 человек, отбывающих наказание в местах лишения свободы по приговору суда / Постановление Европейского Суда по правам человека от 4 июля 2013 г. по делу «Анчугов (Anchugov) и Гладков (Gladkov) против России». 
б) осужденные за совершение преступлений экстремистской направленности, предусмотренных Уголовным кодексом Российской Федерации, и имеющие на день голосования на выборах неснятую и непогашенную судимость за указанные преступления;

в) подвергнутые административному наказанию за пропаганду и публичное демонстрирование нацистской или сходной экстремистской атрибутики и символики, за производство и распространение экстремистских материалов, если голосование на выборах состоится до окончания срока, в течение которого лицо считается подвергнутым административному наказанию;

г) в отношении которых вступившим в силу решением суда установлен факт призывов к экстремистской деятельности, обоснования или оправдания экстремизма, если указанные нарушения либо действия совершены до дня голосования на выборах в течение срока полномочий органа государственной власти или органа местного самоуправления, в которые назначены выборы, либо должностного лица, для избрания которого назначены выборы».

Данные ограничения введены законодателем в целях защиты институтов публичной власти от криминализации. Электоральная практика выборов различного уровня подтверждает обоснованность этих ограничений.

Материалы Аппарата ЦИК России свидетельствуют о регулярном участии представителей криминалитета в избирательных кампаниях и увеличении политической активности данной категории граждан.

Рост активности организованных преступных организаций (сообществ), связанный с попытками избрания в органы государственной власти и органы местного самоуправления, обусловлен заинтересованностью преступных организаций в постоянном наращивании своих доходов, прямой зависимостью официальной и теневой экономической деятельности от политической конъюнктуры в Российской Федерации, желанием руководителей и участников криминальных структур обеспечить личную безопасность. Для представителей криминалитета избрание на выборную должность и получение депутатского мандата представляются исключительно значимыми.

Во-первых, факт наделения бандитов властными полномочиями легализует их криминальное прошлое и ставит под сомнение связи с преступными сообществами (организациями).

Во-вторых, избрание на выборную должность или в представительный орган власти позволяет приобрести депутатскую неприкосновенность и рассчитывать на особый 
порядок производства по уголовным делам, фигурантом которых может являться кандидат.

В-третьих, замещение выборных публичных должностей и принадлежность к органам народного представительства создают видимость реализации бандитами властных полномочий от имени и по поручению народа.

В-четвертых, официальное задействование материальных, финансовых, информационных, юридических и иных ресурсов государства заметно расширяет сферы и силу воздействия преступных сообществ (организаций) на общественные процессы внутри страны и за ее пределами.

С учетом повышения роли политических партий в избирательном процессе важнейшей задачей уголовной разведки и контрразведки стало установление контроля организованных преступных групп над ведущими политическими партиями (региональными отделениями политических партий) и продвижение своих представителей в органы государственной власти, местного самоуправления и избирательные комиссии с использованием партийных структур. В связи с этим заметно возросло число лиц, связанных с криминальной средой, в партийных списках кандидатов на выборах.

Анализ биографических данных кандидатов, выдвинутых политическими партиями, принимавшими участие в выборах депутатов Государственной Думы Федерального Собрания Российской Федерации пятого и шестого созывов, выборах в органы государственной власти субъектов Российской Федерации и органы местного самоуправления административных центров субъектов Российской Федерации 8 сентября 2013 г., сведений о неснятых и непогашенных судимостях, о привлечении к уголовной ответственности, об избрании в отношении некоторых из выдвинутых кандидатов меры пресечения в виде заключения под стражу, основаниях прекращения уголовного преследования данных лиц, указывает на следующие обстоятельства ${ }^{1}$ :

- в выдвинутых и зарегистрированных списках всех политических партий, принимавших участие в выборах, присутствовали кандидаты, привлекавшиеся к уголовной ответственности;

- среди лиц, имеющих погашенную судимость, на выборы выдвигались и были зарегистрированы депутаты Государственной Думы Федерального Собрания Российской Федерации, депутаты законодательных органов государственной власти субъектов Российской Федерации, представительных органов муниципальных образований,

1 Лицо, осужденное за совершение преступления, считается судимым со дня вступления обвинительного приговора суда в законную силу до момента погашения или снятия судимости. 
председатели региональных и местных отделений партий, члены федеральных и региональных руководящих органов политических партий;

- некоторые кандидаты были осуждены по совокупности составов преступлений, отдельные лица имели неоднократные судимости, в т.ч. по тяжким составам;

- в отношении ряда кандидатов проводилось предварительное следствие и избиралась мера пресечения в виде заключения под стражу;

- отдельные кандидаты находились в федеральном розыске.

Следует констатировать, что, несмотря на принимаемые избирательными комиссиями и правоохранительными органами меры, часть граждан, привлекавшихся к уголовной ответственности и имеющих погашенные судимости, была избрана депутатами Государственной Думы Федерального Собрания Российской Федерации, законодательных органов государственной власти субъектов Российской Федерации, представительных органов муниципальных образований.

Многочисленные факты выдвижения и регистрации кандидатов с уголовным прошлым были зафиксированы в ходе выборов в органы государственной власти субъектов Российской Федерации и органы местного самоуправления административных центров субъектов Российской Федерации 8 сентября $2013 \Gamma^{1}$.

Наибольшее количество зарегистрированных кандидатов, представляющих интересы криминальных структур, было отмечено на выборах депутатов Государственного Собрания - Курултая Республики Башкортостан - 13. 11 ранее судимых кандидатов баллотировалось на выборах депутатов Законодательного Собрания Забайкальского края и выборах депутатов Законодательного Собрания Владимирской области. 10 ранее судимых кандидатов участвовало в выборах народных депутатов Республики Саха, 8 - на выборах депутатов Народного Хурала Республики Бурятия, 7 - на выборах в Законодательное Собрание Ростовской области.

Максимальное количество представителей криминалитета на муниципальных выборах 8 сентября 2013 г. было зафиксировано в списках кандидатов в Екатеринбургскую городскую Думу - 7 человек - и Волгоградскую городскую Думу - 5 человек.

1 Официальная статистика избирательных комиссий расходится с данными правоохранительных органов и спецслужб. Это объясняется тем, что избирательные комиссии анализируют участие лиц с криминальным прошлым в избирательных кампаниях только по параметру наличия судимости за совершение тяжких и (или) особо тяжких преступлений, в то время как по информационно-справочным учетам правоохранительных органов и спецслужб регистрируются данные о криминальных связях, участии граждан в деятельности преступных организаций (сообществ), о процессуальных и следственных действиях, проведенных в отношении граждан органами дознания и следствия, а также иная оперативно-значимая информация. 
Процессы криминализации органов власти и управления требуют адекватного реагирования со стороны государства и институтов гражданского общества, реализации последовательной антикриминальной политики.

Как представляется, основные направления противодействия криминализации органов публичной власти в Российской Федерации необходимо выстраивать с учетом существующих международно-правовых стандартов и зарубежного опыта.

Пропорциональность, допустимость и правомерность установления государствами ряда ограничений пассивного избирательного права граждан неоднократно рассматривалась в прецедентной практике Европейского Суда по правам человека.

Статья 25 Международного пакта о гражданских и политических правах допускает введение обоснованных ограничений права и возможности каждого гражданина быть избранным на выборах. Как отмечается в постановлениях Европейского Суда по правам человека по делам «Матье-Моэн и Клерфейт против Бельгии», «Дойл против Соединенного Королевства», право лица выдвигать свою кандидатуру на выборах не носит абсолютного характера ${ }^{1}$. Поскольку статья 3 Протокола № 1 к Конвенции о защите прав человека и основных свобод, признавая это право, не конкретизирует его и тем более не дает ему юридического определения, появляются возможности для введения так называемых имплицитных или подразумеваемых ограничений (постановление по делу «Матье-Моэн (Mathieu-Mohin) и Клерфейт (Clerfayt) против Бельгии»); государства достаточно свободны в рамках своего конституционного строя устанавливать статус парламентариев, включая критерии избираемости (постановление по делу «Гитонас (Gitonas) и другие против Греции», «Подколзина против Латвии», «Дойл против Соединенного Королевства»). Эти критерии различаются в зависимости от исторических и политических особенностей каждого государства.

Во многих зарубежных странах лица, отбывающие наказание в местах лишения свободы по приговору суда ограничены в избирательном праве или лишены егоㄹ. В Австрии, Бельгии, Франции, Германии, Греции, Италии, Люксембурге, Мальте, Нидерландах, Норвегии, Польше, Румынии и Турции существуют ограничения избирательного права заключенных. В Армении, Азербайджане, Болгарии, Эстонии,

${ }^{1}$ Решение Европейского Суда по правам человека от 2 марта 1987 г. по делу «Матье-Моэн (MathieuMohin) и Клерфейт (Clerfayt) против Бельгии» // Европейский Суд по правам человека. Избранные решения: в 2 т. М.: Норма, 2000; Решение Европейского Суда по правам человека от 6 февраля 2007 г. по делу «Дойл (Doyle) против Соединенного Королевства» // Бюллетень Европейского Суда по правам человека. Российское издание. 2007. № 8.

2 Дуксин П.А. Лишение избирательных прав лиц, признанных судом недееспособными, и лиц, содержащихся в местах лишения свободы по приговору суда: справедливость и целесообразность / Сборник конкурсных работ в области избирательного права, избирательного процесса и законодательства о референдуме, выполненных студентами и аспирантами высших юридических учебных заведений Российской Федерации в 2004-2005 году. М.: РЦОИТ, 2005. С. 125-138. 
Грузии, Ирландии, Латвии, Лихтенштейне, Молдавии, Российской Федерации, Словакии и Великобритании заключенные лишены права голоса.

В соответствии с $\S 45$ УК ФРГ лишение пассивного избирательного права осуществляется на срок от 2 до 5 лет. § 22 разд. 2 Положения о порядке проведения выборов в Национальный Совет Австрии (Nationalratswahlordnung 1992) предусматривает лишение осужденных избирательного права на 6 месяцев ${ }^{1}$. В Китае политических (в том числе и избирательных) прав пожизненно лишаются лица, совершившие контрреволюционные преступления, а также осужденные к смертной казни и бессрочному лишению свободы ${ }^{2}$.

По сфере действия лишение избирательного права может распространяться на выборы в конкретном избирательном округе (локальное лишение) или на все виды выборов на всей территории государства (универсальное лишение права). Так, лицо, совершившее коррупционное правонарушение в сфере избирательного права Великобритании (мошенничество, неправомерное давление на избирателей, превышение предельных размеров предвыборных расходов, подкуп, фальсификацию документов о выдвижении кандидата), лишается пассивного избирательного права на 10 лет на территории всей страны. За осуществление незаконной практики (нарушение различных законодательных требований о доверенных лицах, использования помещений, рекламы, освещения предвыборной кампании, голосование более одного раза, голосование, несмотря на лишение права голоса и др.) к правонарушителю применяется лишение пассивного избирательного права на 5 лет на территории конкретного избирательного округа ${ }^{3}$.

По содержанию изъятий объема правосубъектности лишение избирательного права можно классифицировать на лишение активного избирательного права и лишение пассивного избирательного права. Решением Государственного трибунала Польской Республики лицо, совершившее преступление, связанное с нарушением Конституции или законов, может быть лишено как активного, так и пассивного избирательного права на всех видах выборов (п.1 ст. 23 Закона «О государственном трибунале» от 26 марта 1982

\footnotetext{
${ }^{1}$ Bundesgesetz BGB1. Nr. 47/ 1992; BGB1. I Nr. 28/2007.

2 Зарубежное избирательное право: Учебное пособие. М.: Норма, 2003. С. 168.

${ }^{3}$ В соответствии с Актом о народном представительстве 1983 г. (the Representation of the People Act 1983) в избирательном праве Великобритании все правонарушения подразделяются на 2 вида - на коррупцию и незаконную практику (corrupt or illegal practices), что влечет для правонарушителя ограничение пассивного избирательного права. Аналогичная классификация правонарушений в сфере избирательного права принята и в Канаде. См. Зарубежное избирательное право: Учебное пособие. М.: Норма, 2003. С. 86.
} 
г.) ${ }^{1}$. В Канаде пассивного избирательного права лишены лица, отбывающие наказание в местах лишения свободы на срок свыше двух лет ${ }^{2}$.

Либерализация пенитенциарной политики в государствах Европейского Союза привела к изменению правовых позиций органов конституционной юстиции по вопросу защиты избирательных прав осужденных лиц. Так, 6 октября 2005 г. Большая палата Европейского Суда по правам человека вынесла окончательное решение по делу «Херст против Соединенного Королевства» (Hirst v. United Kingdom) (жалоба № 74025/01) 3 . Заявитель, Джон Херст, приговоренный к пожизненному лишению свободы за убийство, обжаловал положения ст. 3 Акта о народном представительстве 1983 г. о запрете принимать участие в голосовании на выборах в Парламент или местные органы власти. Европейский Суд признал несоответствие ст.3 Акта о народном представительстве Протоколу № 1 Конвенции о защите прав человека. По мнению Суда, запрет на участие заключенных в выборах не должен распространяться на всех осужденных, кроме того, данное ограничение должно применяться в зависимости от срока назначенного наказания и тяжести правонарушения. Европейский Суд предоставил Великобритании право самостоятельно избрать способ обеспечения избирательных прав заключенных ${ }^{4}$.

Сформулированная Европейским судом правовая позиция по делу «Херст против Соединенного Королевства» (Hirst v. United Kingdom) о том, что автоматическое и недифференцированное лишение избирательных прав группы лиц независимо от срока наказания, характера или тяжести совершенного правонарушения и личных обстоятельств несовместимо со ст. 3 Протокола № 1 к Конвенции была позднее подтверждена в Постановлении от 8 апреля 2010 г. по делу «Фродль (Frodl) против Австрии» и Постановлении от 22 мая 2012 г. по делу «Скоппола (Scoppola) против Италии», Постановлении от 4 июля 2013 г. по делу «Анчугов (Anchugov) и Гладков (Gladkov) против России».

В Постановлении от 8 апреля 2010 г. по делу «Фродль против Австрии» Европейский Суд напомнил, что «лишение избирательных прав может быть предусмотрено только для преступников, отбывающих длительные сроки лишения свободы; между фактами, положенными в основу осуждения, и санкцией в виде лишения

${ }^{1}$ Современные избирательные системы. Вып. 1: Великобритания, Канада, Мексика, Польша. М.: Норма, 2006. С. 370.

2 Там же. С. 207.

${ }^{3}$ Постановление Европейского Суда по правам человека от 6 октября 2005 г. по делу «Херст против Соединенного Королевства» (Hirst v. United Kingdom) (жалоба № 74025/01) // Бюллетень Европейского Суда по правам человека. Российское издание. 2006. № 4.

${ }^{4}$ В государствах, где заключенные имеют право голоса (Албания, Босния и Герцеговина, Кипр, Хорватия, Чехия, Дания, Финляндия, бывшая югославская республика Македония, Исландия, Литва, Португалия, Словения, Испания, Швеция, Швейцария и Украина), они реализуют свое избирательное право путем голосования по почте, по доверенности и другими предусмотренными законом способами. 
избирательных прав должна быть прямая связь; и такая мера должна предпочтительно применяться не в силу действия закона, а по решению судьи по результатам судебного разбирательства» ${ }^{1}$.

В Судебном решении от 22 мая 2012 г. по делу «Скоппола против Италии» Европейский Суд указал, что «меры ограничения избирательных прав заключенных неодинаковы в различных национальных правовых системах. Государства-участники могут отнести пропорциональность меры ограничения избирательных прав заключенных на усмотрение судов или включить в законодательство положения, определяющие обстоятельства, при которых применяется такая мера. В последнем случае сам законодатель должен сопоставить конкурирующие интересы в целях избежания любого автоматического и неизбирательного ограничения» ${ }^{2}$.

Наиболее серьезные политико-правовые последствия для Российской Федерации имеет Постановление Европейского суда по правам человека от 4 июля 2013 г. по делу «Анчугов (Anchugov) и Гладков (Gladkov) против России». В деле «Анчугов и Гладков против России» Страсбургский суд со ссылкой на правовую позицию по делу «Херст против Соединенного Королевства» признал, что часть 3 статьи 32 Конституции Российской Федерации нарушает ст. 3 Протокола № 1 к Европейской Конвенции, гарантирующую право на свободные выборы. В ответ на аргументы властей Российской Федерации, что данное дело отличается от дела «Херст против Соединенного Королевства», поскольку в России запрет заключенным на участие в выборах установлен Конституцией Российской Федерации, принятой всенародным голосованием, а не «обычным законом», Европейский Суд указал, что Конвенция распространяется на любые нормы и меры, относящиеся к юрисдикции национальных властей, которые реализуются именно через Конституцию.

Страсбургский суд постановил, что власти не представили доказательств того, что в ходе широких общественных обсуждений проекта Конституции Российской Федерации рассматривался вопрос о пропорциональности оспариваемого ограничения общественным интересам. Оспаривая позицию российской стороны о том, что изменение ст. 32 Конституции Российской Федерации представляет собой сложную процедуру (невозможность пересмотра Федеральным Собранием, необходимость поддержки

1 Постановление Европейского Суда по правам человека от 8 апреля 2010 г. по делу «Фродль против Австрии» (Frodl v. Austria) (жалоба №20201/04) // Информационный бюллетень по прецедентной практике Европейского Суда по правам человека. 2010, № 129.

2 Постановление Европейского Суда по правам человека от 22 мая 2012 г. по делу «Скоппола против Италии» (Scoppola v. Italy) (жалоба № 74025/01) // Бюллетень Европейского Суда по правам человека. Российское издание. 2012, № 11. 
предложения о пересмотре $3 / 5$ голосов от общего числа членов Совета Федерации и депутатов Государственной Думы, созыв Конституционного Собрания) Европейский суд по правам человека указал, что способ исправления выявленного нарушения остается на усмотрение государства-ответчика, находясь при этом под надзором Комитета министров Совета Европы ${ }^{1}$. И государство вполне может прибегнуть с этой целью к тому или иному политическому процессу или истолковать Конституцию соответствующим образом.

Представляется, что комментируемое Постановление Европейского Суда по правам человека ставит под сомнение принцип верховенства Конституции Российской Федерации (часть 1 статьи 15 Конституции) и тем самым нарушает суверенитет нашего государства. Мнение нескольких десятков судей Европейского Суда перечеркивает юридическое волеизъявление миллионов российских граждан по вопросам государственной и общественной жизни, выраженное в Конституции. Именно многонациональный народ России, а не Страсбургский Суд, приняв на всенародном голосовании в 1993 г. Конституцию Российской Федерации, определил характеристики и пределы государственной власти, условия и процедуры реализации прав граждан на участие в управлении делами общества и государства, механизмы защиты государственной власти.

Российская Конституция не допускает иных носителей суверенитета и источников власти, кроме народа Российской Федерации, а статья 79 Конституции не предусматривает уступки или возможности деления суверенитета Российской Федерации с международным сообществом.

10 октября 2013 г. позиция Европейского Суда по проблеме ограничения избирательного права в связи с наличием судимости была учтена Конституционным Судом Российской Федерации при вынесении решения по делу «О проверке конституционности подпункта «а» пункта 3.2 статьи 4 Федерального закона «Об основных гарантиях избирательных прав и права на участие в референдуме граждан Российской Федерации», части первой статьи 10 и части 6 статьи 86 УК РФ в связи с жалобами граждан Г.Б.Егорова, А.Л.Казакова, И.Ю.Кравцова, А.В. Куприянова, А.С. Латыпова и В.Ю. Синькова» ${ }^{2}$.

Проблема защиты избирательных прав осужденных рассматривалась Конституционным Судом Российской Федерации в системной взаимосвязи с выявлением сущности и публично-правовых последствий судимости. Как указал Конституционный

1 Состав, порядок формирования и деятельности Конституционного Собрания должен быть урегулирован Федеральным конституционным законом «О Конституционном Собрании Российской Федерации», который до настоящего времени не принят.

2 Постановление Конституционного Суда Российской Федерации от 10 октября 2013 г. № 20-П // Рос. газ. 2013. 23 октября. 
Суд в Постановлении от 19 марта 2003 г. № 3-П «По делу о проверке конституционности положений Уголовного кодекса Российской Федерации, регламентирующих правовые последствия судимости лица, неоднократности и рецидива преступлений, а также пунктов 1-8 постановления Государственной Думы Федерального Собрания Российской Федерации от 26 мая 2000 г. «Об объявлении амнистии в связи с 55-летием Победы в Великой Отечественной Войне 1941-1945 годов» в связи с запросом Останкинского межмуниципального (районного) суда города Москвы и жалобами ряда граждан», «судимость представляет собой правовое состояние лица, обусловленное фактом осуждения и назначения ему по приговору суда наказания за совершенное преступление» ${ }^{1}$.

Состояние судимости носит срочный характер. Судимость возникает при осуждении лица за совершение преступления со дня вступления обвинительного приговора суда в законную силу и прекращается в момент погашения или снятия.

Далеко не всегда снятие или погашение судимости аннулирует ее правовые последствия. Наличие у лица судимости порождает особые публично-правовые отношения с государством.

Правовые последствия судимости позволяют предъявлять строгие требования к возможному криминальному прошлому лиц, претендующих на замещение должностей судей, прокуроров, полицейских, сотрудников спецслужб, а также работников сферы образования, воспитания, отдыха, медицинского обеспечения, социальной защиты несовершеннолетних, детско-юношеского спорта, культуры и искусства.

Согласно пункту 1 статьи 4 Закона Российской Федерации «О статусе судей в Российской Федерации», пункту 2 статьи 40.1 Закона Российской Федерации «О прокуратуре Российской Федерации», пунктам 2 и 3 части 1 статьи 29 Федерального закона «О полиции», подпункту 4 пункта 5 статьи 18 Федерального закона «О государственной охране», пункту «в» части 3 статьи 16 Федерального закона «О федеральной службе безопасности», пункту 2 части 4 статьи 16 Федерального закона «О Следственном комитете Российской Федерации» гражданин, имеющий судимость (в том числе снятую или погашенную), а также в отношении которого уголовное преследование прекращено за истечением срока давности, в связи с примирением сторон, вследствие акта об амнистии или в связи с деятельным раскаянием, никогда не сможет поступить на службу или на работу в органы прокуратуры, полиции, органы государственной охраны, федеральной службы безопасности, следственные органы, не может быть назначен на должность судьи.

\footnotetext{
1 Рос. Газ. 2003. 2 апреля.
} 
Данные требования представляются логичными.

Ни у кого не вызывает возражений запрет на трудовую деятельность в сфере образования, воспитания, развития несовершеннолетних, организации их отдыха и оздоровления, медицинского обеспечения, социальной защиты и социального обслуживания, в сфере детско-юношеского спорта, культуры и искусства с участием несовершеннолетних в отношении лиц, имеющих или имевших судимость, подвергающихся или подвергавшихся уголовному преследованию за преступления против жизни и здоровья, свободы, чести и достоинства личности, половой неприкосновенности и половой свободы личности, против семьи и несовершеннолетних, здоровья населения и общественной нравственности, основ конституционного строя и безопасности. В соответствии со статьей 351.1 Трудового кодекса Российской Федерации для всех перечисленных выше лиц наличие справки об отсутствии судимости является обязательным документом для заключения трудового договора.

В судебной практике наличие судимости связывается с фактом отбывания (или неотбывания) наказания. В соответствии с ч. 2 ст. 86 УК РФ лицо, освобожденное от наказания, считается несудимым. В п. 5 постановления Пленума Верховного Суда СССР от 18 марта 1970 г. № 4 (с изм. и доп., внесенными постановлениями Пленума Верховного Суда СССР от 21 сентября 1977 г. № 11; от 26 апреля 1984 г. № 7) «Об исчислении срока погашения судимости» указано, что «при постановлении обвинительного приговора без назначения наказания, а также с освобождением осужденного от наказания в силу акта амнистии или в связи с истечением давностного срока виновный, как не отбывавший наказание, признается не имеющим судимости, независимо от продолжительности предварительного заключения» ${ }^{1}$.

Постановление Конституционного Суда Российской Федерации от 10 октября 2013 г. № 20-П подтвердило конституционность ограничения пассивного избирательного права для граждан, осужденных за тяжкие и особо тяжкие преступления: «правовая демократия требует надежно защитить ее от злоупотреблений и криминализации публичной власти, легитимность которой во многом основывается на доверии общества. Исходя из этого, запрет занимать выборные публичные должности для лиц, совершивших тяжкие и особо тяжкие преступления, преследует конституционно значимые цели. ...Ограничение пассивного избирательного права введено федеральным законодателем в качестве особого

${ }^{1}$ Постановление Пленума Верховного Суда СССР от 18 марта 1970 г. № 4 «Об исчислении срока погашения судимости» // Сб. постановлений Пленума Верховного Суда СССР 1924-1977. Ч.2. М.: Известия, 1978; Постановление Пленума Верховного Суда СССР от 21 сентября 1977 г. № 11 «Об изменении и дополнении постановления Пленума Верховного Суда СССР от 18 марта 1970 г. № 4 «Об исчислении срока погашения судимости». [Текст не опубликован.] 
конституционно-правового дисквалифицирующего препятствия для занятия выборных публичных должностей, сопряженного с повышенными репутационными требованиями к носителям публичной (политической) власти, что обусловлено их прямым участием в принятии правовых актов (нормативных и индивидуальных) и ответственностью, с которой связано осуществление ими своих полномочий» ${ }^{1}$.

В тоже время бессрочное и недифференцированное ограничение пассивного избирательного права в отношении граждан Российской Федерации, осужденных к лишению свободы за совершение тяжких и (или) особо тяжких преступлений, не являющееся уголовным наказанием, признано Конституционным Судом не соответствующим статьям 3 (части 2 и 3), 15 (часть 4), 17 (часть 3), 19 (части 1 и 2), 32 (части 1, 2 и 3) и 55 (части 2 и 3) Конституции Российской Федерации ${ }^{2}$. Как постановил Конституционный Суд Российской Федерации, в приговоре должен указываться срок конституционно-правового дисквалифицирующего препятствия для занятия осужденными лицами выборных публичных должностей после отбытия ими наказания.

По мнению Конституционного Суда Российской Федерации, сроки вводимых федеральным законом ограничений пассивного избирательного права, по общему правилу, должны устанавливаться соответственно дифференциации сроков судимости, предусмотренной УК РФ³ тяжкие преступления, исходя из повышенной степени их общественной опасности, федеральным законом могут вводиться ограничения пассивного избирательного права и на более продолжительные сроки с соблюдением конституционных критериев соразмерности и необходимости.

Конституционный Суд Российской Федерации также обязал федерального законодателя установить процессуальные гарантии, обеспечивающие возможность восстановления пассивного избирательного права граждан, судимость которых снята или погашена, в случае принятия нового уголовного закона, в соответствии с которым совершенное ими деяние более не признается тяжким или особо тяжким преступлением.

Проведенный анализ конституционно-правовой доктрины позволяет сделать следующие выводы:

\footnotetext{
${ }^{1}$ Рос. газ. 2013. 23 октября.

2 Рос. газ. 2013. 23 октября.

${ }^{3}$ Согласно законопроекту, внесенному в Государственную Думу после принятия Конституционным Судом Российской Федерации Постановления от 10 октября 2013 г. № 20-П, осужденные когда-либо к лишению свободы за совершение тяжких преступлений, за исключением случаев, когда, в соответствии с новым уголовным законом, эти деяния не признаются тяжкими преступлениями, не смогут баллотироваться в течение 10 лет со дня снятия или погашения судимости, а осужденные когда-либо к лишению свободы за совершение особо тяжких преступлений - в течение 15 лет со дня снятия или погашения судимости.
} 
1. Правовые позиции судебных органов свидетельствуют о дальнейшей унификации подходов европейских и российских органов конституционной юстиции в отношении критериев избираемости и активного избирательного права, что обусловливает необходимость внесения изменений в национальное законодательство Российской Федерации. Постановления Европейского Суда по правам человека от 6 октября 2005 г. по делу «Херст (Hirst) против Соединенного Королевства», от 8 апреля 2010 г. по делу «Фродль (Frodl) против Австрии» и от 22 мая 2012 г. по делу «Скоппола (Scoppola) против Италии», от 4 июля 2013 г. по делу «Анчугов (Anchugov) и Гладков (Gladkov) против России», Постановление Конституционного Суда Российской Федерации от 10 октября 2013 г. № 20-П по делу «О проверке конституционности подпункта «а» пункта 3.2 статьи 4 Федерального закона «Об основных гарантиях избирательных прав и права на участие в референдуме граждан Российской Федерации», части первой статьи 10 и части 6 статьи 86 УК РФ в связи с жалобами граждан Г.Б.Егорова, А.Л.Казакова, И.Ю.Кравцова, А.В. Куприянова, А.С. Латыпова и В.Ю. Синькова» подразумевают, что пассивное избирательное право должно быть предоставлено: лицам, которым наказание назначено условно; освобожденным от наказания; амнистированным и помилованным; лицам, которым приговором суда не назначено наказание в виде лишения права занимать определенные должности ${ }^{1}$.

2. Законодательное регулирование конституционных ограничений прав и свобод граждан направлено на приведение сроков ограничений пассивного избирательного права осужденных в соответствие со степенью общественной опасности составов преступлений, видом наказания (лишение свободы) и сроками судимости. Осужденные за совершение тяжких преступлений к лишению свободы лишаются права баллотироваться в течение 10 лет со дня снятия или погашения судимости, а осужденные за совершение особо тяжких преступлений - в течение 15 лет со дня снятия или погашения судимости. Предусмотренную Конституционным Судом Российской Федерации в Постановлении от 10 октября 2013 г. № 20-П возможность ограничения пассивного избирательного права на более продолжительные сроки целесообразно распространить на следующие составы, предусмотренные ст.ст. 205 «террористический акт», 208 «организация незаконного вооруженного формирования или участие в нем», 209 «бандитизм», 210 «организация преступного сообщества (преступной организации) или участие в нем (ней)», ст. 211

${ }^{1}$ Согласно статье 311 УПК РФ в случае вынесения обвинительного приговора без назначения наказания; обвинительного приговора с назначением наказания и с освобождением от его отбывания; обвинительного приговора с назначением наказания, не связанного с лишением свободы, или наказания в виде лишения свободы условно подсудимый, находящийся под стражей, немедленно освобождается в зале суда. 
«угон судна воздушного или водного транспорта либо железнодорожного подвижного состава», 275 «государственная измена», 277 «посягательство на жизнь государственного или общественного деятеля», 278 «насильственный захват власти или насильственное удержание власти», 279 «вооруженный мятеж» Уголовного кодекса Российской Федерации.

3. Имплементация международных стандартов в российское законодательство актуализирует значимость судебной практики назначения уголовных наказаний в виде лишения права занимать выборные должности. Модернизация материальных и процессуальных норм в соответствии с международными стандартами потребует от организаторов выборов единообразной практики уточнения степени тяжести преступлений с учетом периода действия разных редакций уголовного закона.

4. Наиболее серьезные политико-правовые последствия для Российской Федерации имеет Постановление Европейского суда по правам человека от 4 июля 2013 г. по делу «Анчугов (Anchugov) и Гладков (Gladkov) против России», в котором оспаривается верховенство Конституции Российской Федерации и нарушается суверенитет Российской Федерации в части определения характеристик и пределов государственной власти, условий и процедур реализации прав граждан на участие в управлении делами общества и государства. В связи с этим в целях предупреждения дальнейших попыток ограничения суверенитета Российской Федерации, подрыва принципа верховенства Конституции, вмешательства международных организаций в нашу систему народовластия необходимо привести ратифицированные Российской Федерацией международные договоры и связанные с ними обязательства в соответствие с интересами защиты конституционного строя. При всем уважении к Страсбургскому суду Конституцию России нужно любить, уважать и твердо отстаивать.

Красинский Владислав Вячеславович доктор юридических наук, член Общественного консультативного научно-методического Совета при ЦИК России 109012, г. Москва, Б. Черкасский пер. д. 4 стр. 2 м.т. 8985-364-61-15 e-mail: vkr@fromru.com 